\title{
FISHERY RESEARCH IN MICHIGAN
}

\author{
Carl L. Hubs \\ Institute for Fisheries Research, University of Michigan
}

It is a strenuous problem with which we all are faced: to maintain and if possible to increase our game fish population, in the face of an ever increasing tendency toward depletion. This problem is a challenge to the energy and ingenuity of the peoples of North America. Its successful solution will take all we can put into it.

Two main forces can be brought into play to stem, and we hope eventually to turn back, this tide of depletion. One of these forces is a vigorous and intelligent administration of the inland fisheries. By this I mean of course the passing of wise fishing regulations, and their proper enforcement; extensive activity in artificial and semiartificial propagation; the protection of spawning grounds and nursery waters, where desirable, and the modification of natural waters in one way or another so as to increase their productivity.

The second force which needs be brought into action to stem or turn back the tide of depletion of our fish supply is scientific investigation. In the great movements now under way to conserve and develop the fisheries, investigation is playing a prominent part. This is true the world around-I have seen the recent developments of the field of fishery research in lands as far away as Java and Japan. It is becoming generally recognized that fishery research is fundamental to sound and effective fishery administration.

Fishery research, like any science, has no political boundaries. Nevertheless each government needs maintain a scientific fisheries staff: firstly, to carry as good sports a share in this necessary work; secondly, to appreciate the scientific results obtained elsewhere in like investigations; thirdly, to adapt the results to local conditions; fourthly, to carry on investigations in fields which are of peculiarly local significance; fifthly, to train men to carry on the fishery investigations of the future, toward which we must increasingly turn our eyes; and sixthly, to help train future administrators, that they may effectively carry out and practically apply the results of the investigation.

Realizing these circumstances, Michigan is following the general tendency toward an increase in fishery research. Some time after the tragic and serious loss of Dr. Jan Metzelaar, the Michigan Department of Conservation inquired of the University of Michigan whether it would be willing to carry on for the Department the fishery investigations within the State. The University agreed to do this. Before I go on with a discussion of the organization of our fish research service, I feel constrained to pause long enough to pay tribute to the man I have just mentioned, and whom many of you knew.

To America, as a land of promise and opportunity, Dr. Jan Metzelaar came in November of 1923. Almost immediately he entered 
upon his duties as Fisheries Expert for the Michigan Department of Conservation. From the first, his headquarters were maintained in the Division of Fisheries at the University. Metzelaar became fondly attached to this land he had adopted, and was made supremely happy by being admitted as a citizen of the United States on October 2, 1929. Just two days later he was drowned in Grand Lake, near Alpena. He died on duty, while carrying on his fish investigations. Thus, before the end of his thirty-eighth year, Jan Metzelaar joined the heroic band of martyrs to his science. This man, whose life was so tragically cut short, was born in the Netherlands on October 21, 1891 , and he received a thorough education, ending in special training in ichthyology and fishery biology. After coming to America, Metzelaar carried on as his chief occupation, his duties as State Fisheries Expert. In this work he was fired by a tremendous enthusiasm, so real that no one could doubt his sincerity. He was staunchly loyal to his friends, and to the state departments with which he was connected; and even-tempered and generous toward the rivals and opponents which the nature of his official work una voidably engendered; that indeed is a high tribute to the character of the man. He was ever ardent as a conservationist, and painfully disturbed at the way we Americans almost ruthlessly destroy our natural resources.

Metzelaar's activities were many. So pressing was the call for hundreds of minor investigations, and so limited the staff-a general curse in fisheries biology-that most of his work cannot be classed as major projects. He vigorously and successfully carried along the intensive survey of hundreds of trout streams of Michigan, with a view toward better policies and programs for replenishing the trout supply, and during the last two or three years, he similarly contributed to the fisheries survey of the inland lakes-a work on which he was engaged when he met his untimely death. He also made investigations on problems in trout propagation, such as the control by diet of goiter in hatchery trout. His very thorough studies of the food of the three species of stream trout in the state, and of their competitive inter-relations, have attracted very favorable attention. Many returns are now coming in from his extensive trout-tagging experiments, which are giving us evidence of the migrations of these fishes. Metzelaar's other investigations dealt with the status of the smelt in our waters, the proper conditions for wall-eyes; the growth of that species, and the difficulties encountered in its artificial propagation and conservation; the food of other species than trout; the time of spawning of game fish in reference to the open season, and the improvement of trout streams by the introduction of snags. Metzelaar did his work well, under many difficulties, and laid a foundation for us to build on.

A second fish investigator until recently with the Department of Conservation, T. H. Langlois, has now become the state superintendent of fish culture for Ohio. He also was located at the University 
in which he had been trained, and he also gave good service to the state.

A third fish investigator, Dr. Walter Koelz, formerly of the Bureau of Fisheries, also a product of the University of Michigan, was employed by the Department of Conservation just before the University agreed to take over this field of work. He joined the fishery staff of the University but soon left to take an important post as a biological explorer in upper India.

It has become necessary for us, therefore, to build up a new staff of fishery investigators. This is a handicap to us at the start, but we expect to develop gradually an efficient and effective organization. To the position of fish pathologist we have appointed Wendell $H$. Krull. As assistant to the Director we have taken over Dr. John R. Greeley, well known for his work in the New York Biological Survey. As assistants and fellows we have eight young men of promise.

To care for this work the University of Michigan has established a new unit, known as The Institute for Fisheries Research, of which it is my lot to serve as Director during the period of organization. This department is financed largely by the Michigan Department of Conservation, with a very substantial additional subsidy from The Michigan Division of the Izaak Walton League of America.

The location of the Institute at the University of Michigan has a number of distinct advantages. It gives us the advantages of good laboratory and library facilities, of experimental aquaria, of a group of specialists ready to help us in their particular lines of work, as fish parasitology for example. And it gives us the advantage of obtaining student assistants, who are being trained to further the same line of work. And it further gives us the advantages of association with the Great Lakes Laboratory of the Bureau of Fisheries, which is housed in adjacent rooms, and which under Dr. Van Oosten is carrying on the investigations of the commercial fisheries in the Great Lakes.

We are attempting to initiate an enlarged fisheries research program in Michigan. A hasty summary of the present main activities of the Michigan Institute for Fisheries Research may be of some interest to members of the American Fisheries Society.

(1) Creel census.-For nearly four years the Michigan Department of Conservation has been obtaining records from fishermen of their catch-number of legal size fish of each species caught, number of fish below legal size caught and thrown back, number of hours fishing, etc. We obtain not a census of the total fish catch, but a measure of intensity, as fish caught per hour of sport fishing. This year the number of records is being greatly increased over the ten thousand obtained the previous year. The Institute is analyzing these statistics.

(2) Lake and stream survey.-The inventory of Michigan lakes and streams, with special reference to fish population, fish and fishing 
conditions, and possible improvements in fish management, is being extended and intensified this year. This is particularly true of the lake work, thanks to the splendid co-operation of the Michigan Division of the Izaak Walton League of America. The League has provided fellowships in the University for three men being trained in problems of the development of the inland lake sport fisheries. These men, Eschmeyer, Ashley and Jones, this summer began their work by mapping and studying in detail all the lakes of Kalkaska County, Michigan.

(3) Modifying conditions in natural waters.- One of the great hopes of the Institute is to test out the practicability of modifying natural conditions so as to make for a greater fish yield. Places are underway for experiments in increasing weed beds on barren bottom, in introducing gravel spawning beds where deficient and in resnagging trout streams. The problem of introducing current-modifying barriers in trout streams is being actively carried on this summer, by Clarence Tarzwell. We are finding that it is by such means possible to improve trout conditions by increasing the number of holes in which trout find their homes, by increasing the shelter which will serve to protect them, by increasing the riffle areas in which trout love to feed, by increasing the weed beds so productive of trout food and so needed for the shelter of young trout. Each barrier placed now or in the last two years in the stream, as well as many natural barriers, are being copper-tagged, so that the permanence of the barriers and their effect on the stream may be followed from year to year.

(4) Nursery waters.- Studies are being made of the nursery waters of various species, with the points in mind of finding the most suitable places to plant young fishes of different stages, and of determining the utility of closing nursery waters, especially feeder trout streams. Dr. Greeley has immediate charge of these studies.

(5) Migration studies.-Extensive studies of trout movements by the tagging method are being continued in Michigan. Especially striking is the evidence of the great wanderings of rainbow trout, and the sedentary habits over most of Michigan of the brook trout.

(6) Predator studies. - Chief stress is now being paid to the concluding of an investigation, by Canuto Manuel, of the relation of the common term to the commercial fishes and fisheries. The results of this study appear to be gratifyingly conclusive. Material is also being gathered for a study, by J. Clark Salyer, of many other fish predators, not only birds but also fishes, mammals and reptiles.

(7) Fish diseases.-The diseases of Michigan fishes, both in hatcheries and nature, are being studied by the Fish Pathologist, Wendell H. Krull. Particular attention is being given the study of the many bacterial diseases which we find to be the chief maladies causing mortality among our fishes. The end will always be kept in view of trying to determine means of preventing the diseases, as of more 
importance than the nevertheless necessary search for methods of treating the diseases once they have become epidemic.

(8) Fish survey.-The general ichthyological survey of the state, a corollary of the lake and stream survey, is being continued as for years past. This work has already led to a number of refinements in the classification of our fishes and will eventually head into a general treatise on Michigan fishes. One study of a special group, the ciscoes, or coregonid fishes, of the inland lakes of Michigan and adjoining regions, was completed by Dr. Walter Koelz while serving as Ichthyologist of the Institute.

(9) Dwarfing analysis.-A study of the extremely important question as to the real meaning of the dwarfing of perch and other fish species has been begun. This study will be conducted by Samuel N. Jones

(10) Growth investigations.-Much material is being gathered for a study of the growth rate, age and size at maturity, relation of growth to different natural conditions, etc. Experimental studies have been made on forced over-winter growth, and on the formation of growth marks on the scales and on increased growth induced by hybridization in the sunfish family.

It is the intention of this new Institute for Fisheries Research to study those problems which have a possible practical application in sight, and to carry on the investigations on a sufficiently large scale to make the results of as immediate applicability as possible. 